\title{
BISNIS FIRST TRAVEL DAN DAMPAK BURUKNYA
}

\section{Soleh Setiajiamin}

Prodi : Teknik Industri Universitas Katolik Widya Mandala Surabaya di Madiun

\section{Solehsetiaji97@gmail.com}

\begin{abstract}
Abstrak :
Manusia merupakan manusia yang berakal budi, manusia sesungguhnya berasal dari tanah dan akan kembali ke tanah. Sehingga perbuatannya juga harus seperti tanah, memberi kehidupan, tetapi banyak manusia yang keliru dalam menjalani hidupnya,manusia merupakan makhluk homo sapiens yang artinya makhluk berpikir. Secara teori ada dua sifat pembentuk manusia, yakni egoistik dan altruistik, dalam teori sosialitas aku dan yang lain, first travel tidak peduli dengan yang lain. Ada dua konsep kebebasan dalam manusia yakni deterministik dan indeterministik .pada kasus first travel. Jika dikaitkan dengan pembahasan menurut teori manusia yang berasal dari tanah dan akan kembali ke tanah,perbuatan manusia ternyata melampaui sifat dari tanah, dimensi dasar manusia mengenai sosialitas,manusia hidup dalam dan juga soal intelek,kehendak dan dinamika manusia. Pada kasus fisrt travel banyak terdapat kesalahan dalam hidupnya, dalam menjalani bisnis yang keliru. Manusia menurut teori dinamika realitas adalah makhluk aktif, makhluk yang harus menyeimbangkan antara badaniah dan spiritual.
\end{abstract}

Kata kunci : homo sapiens, sosialitas aku dan yang lain, deterministik dan indeterministik

\section{A. PERMASALAHAN ATAU FENOMENA YANG DIANGKAT}

Kondisi atau permasalahan yang diangkat dalam tugas paper mata kuliah Filsafat Manusia ini adalah, kasus biro perjalanan umroh first travel yang telah memakan banyak korban, dan kerugian yang diterima oleh korban atau jamaah first travel yang tidak mendapatkan ganti rugi. Kasus ini ditinjau dengan teori dalam kuliah filsafat manusia, diantaranya pada bab dimensi dasar manusia, dan pendapat para filsuf tentang manusia yang berasal dari tanah dan kembali ke tanah, Bab III yakni soal Intelek, Kehendak, dan Dinamika manusia. 


\section{B. TEORI YANG DIGUNAKAN}

Teori yang akan digunakan untuk membahas persoalan yang diangkat dalam paper ini, atau persoalan yang disebabkan oleh bisnis biro perjalanan Fisrt Travel, yaitu pandangan para filsuf mengenai anggapan mereka bahwa manusia asalnya dari tanah dan akan kembali ke tanah, dimensi dasar manusia mengenai sosialitas yang didalamnya ada makna aku dan yang lain, serta pembahasan mengenai intelek, Kehendak, dan Dinamika manusia yang didalamnya terdapat makna dinamika manusia sebagai realitas.

\section{PEMBAHASAN MASALAH dan FENOMENA}

Manusia atau dalam bahasa latin disebut homo yang berasal dari bahasa latin humanus yang berarti terpelajar. Sedangkan kata "manusia" dalam bahasa indonesia berasal dari bahasa sanskerta "manu" yang artinya berpikir, berakal budi atau makhluk yang berakal budi. Sehingga dalam bahasa indonesia kemudian dapat diartikan sebagai makhluk yang berakal budi dan memiliki kemampuan untuk menguasai makhluk lain. Pendapat lain yakni dalam bahasa sanskerta manusia berasal dari kata "manusya" dalam bahasa inggris yakni human, dan dari kata latin homo yang berasal dari kata tanah (humus). Dengan pengartian tersebut, dapat ditarik kesimpulan bahwa tidak boleh terlalu mengagungkan manusia. Karena sejatinya semua manusia berasal dari bahan baku yang sama yakni tanah.

Jika saya memaknai teori ini.sejatinya hidup manusia hanyalah sebentar, hidup manusia haruslah menjadi seperti tanah, yang memberi kehidupan untuk makhluk hidup lain seperti hewan, tumbuhan dan juga manusia. Janganlah dalam hidup yang hanya singkat ini diisi oleh keburukan. Saya pernah mendengarkan pepatah jawa yang mengatakan bahwa "Urip iku Urup" yang artinya adalah hidup itu harus menyala, atau memberi penerangan bagi yang lain. Jika saya mengartikan dari pepatah ini, manusia yang hidup haruslah memberi penerangan atau pencerahan atau lebih spesifik lagi hidup manusia haruslah bermanfaat bagi orang banyak. Oleh karena pepatah jawa tersebut saya berpendapat bahwa hidup haruslah diisi dengan kebaikan, tidak peduli seberapa banyaknya dan seberapa seringnya. Hidup harus memberi manfaat untuk yang lain. Harus memberi kebaikan untuk orang banyak. Dari pepatah ini tidak disebutkan bahwa hidup adalah untuk menumpuk kekayaan. Akan berbeda sekali dengan yang dilakukan oleh pemilik bisnis first travel dia hanya berusaha menumpuk kekayaan, tanpa mengusahakan untuk menumpuk kebaikan. Hal ini terlihat dari cara nya menumpuk harta, dengan cara membohongi orang banyak. Orang semacam ini lupa bahwa harta 
yang dimiliki sebanyak apapun, akhirnya tidak akan dibawa mati. Jadi untuk apa orang ini menumpuk harta, terlebih lagi didapatkan dengan menipu orang banyak.

Manusia adalah makhluk yang berakal budi, Karena manusia berakal budi, manusia juga disebut dalam bahasa latin sebagai homo sapiens, sebuah spesies primata dari golongan mamalia yang dilengkapi otak berkemampuan tinggi atau bisa dikatakan manusia adalah hewan rasional. Akal budi atau intelegensi merupakan kemampuan untuk memecahkan masalah dan kemampuan yang dapat beradaptasi. Intelegensi yang dimiliki oleh manusia memberikannya kemampuan untuk menyesuaikan diri dengan lingkungannya atau memahami eksistensinya, serta memberikannya sebuah tujuan dalam hidup ini. Sehingga manusia tidak hanya sekedar exist (ada) di dunia, namun ia memahami dan memiliki sebuah tujuan dalam hidupnya. Manusia adalah makhluk yang memiliki intelegensi atau kecerdasan atau juga disebut sebagai makhluk rasional yang memiliki tujuan dalam hidup. Para filsuf mengatakan bahwa tujuan manusia hidup adalah memproduksi kebaikan yang nantinya sebagai bekal menuju dunia yang kekal diatas sana. Tentunya manusia sudah jelas tujuan diciptakannya, yakni untuk memproduksi kebaikan. Namun saat ini yang terjadi adalah manusia banyak yang tidak mengerti tujuan hidupnya, atau juga keliru dalam menentukan tujuan hidupnya, atau bisa juga disebut kurang lengkap dalam mengutarakan tujuan hidupnya. Ketika ditanya “tujuanmu hidup seperti apa?" dengan pertanyaan ini akan muncul banyak jawaban misalnya ingin sukses karir, menjadi pengusaha, menjadi dosen,tentara, dan lain sebagainya. Tetapi manusia ini lupa bahwa tujuan hidup bukan hanya untuk di dunia saja, melainkan untuk yang diatas sana. Pemahaman seperti ini cukup penting untuk diberikan sejak dini atau bagi mereka yang sudah cukup umur untuk memikirkan tujuan hidup mereka. Jangan sampai tujuan dari manusia keliru. Akan berdampak buruk bagi kehidupannya kelak, jika manusia sampai keliru dalam menentukan tujuan hidupnya.

Manusia dengan demikian adalah materi - intelegensi atau intelegensi yang berwujud. Menurut asal katanya intelegensi berasal dari kata latin yakni intus yang artinya 'dalam' dan kata legere yang berarti membaca dan menangkap'. Sehingga arti kata intelegensi berarti membaca dimensi dalam segala hal. Oleh sebab hakikat manusia adalah materi intelegensi, maka kebutuhan manusia untuk mempertahankan hidupnya tidak hanya sebatas yang bersifat materi seperti makan, minum, istirahat dll, melainkan juga kebutuhan untuk menghasilkan sesuatu sebagai hasil intelegensinya (berkreasi).

Manusia jika dijelaskan dengan bahas sederhana merupakan manusia yang berpikir, tidak hanya untuk makan tapi juga untuk berkreasi di hidupnya. Manusia akan 
menjadi pembeda dengan manusia lainnya yakni dilihat dari tingkat inntelegensinya, manusia memang secara struktur materi sama tetapi kapasitas berpikir tiap individu bisa jadi tak sama. Sehingga setiap manusia akan beda dalam memanfaatkan intelegensinya. Apakah menggunakan untuk kebaikan atau keburukan akan tergantung yang namanya hati nurani manusia. Hati nurani inilah yang menjadi pertimbangan manusia dalam berkreasi. Akan tetapi hasil berkreasi ini juga apakah berdampak positif atau negatif bagi manusia yang lain. Seperti baru-baru ini kasus yang sedang ramai dibicarakan yakni kasus penipuan jamaah umroh first travel. Dalam kasus tersebut pimpinan bisnis perjalanan ini memanfaatkan intelegensinya dalam berbisnis dengan keliru. Mengapa keliru?? Karena pebisnis ini memanfaatkan uang orang lain untuk kepentingan pribadi. Terlebih lagi dia mempermainkan uang untuk kegiatan ibadah, yang tentunya siapa terdapat dalil yakni siapa yang mengganggu orang lain dalam beribadah akan menanggung dosa besar. Menurut dimesi dasar manusia sosialitas fenomen sosial. Sosialitas mengandung didalamnya sistem sosial. Dalam sistem sosial inilah akhirnya terbentuk relasi sosial, semua orang bisa terlibat dalam berbagai relasi tersebut. Untuk relasi sendiri ada yang bersifat kodrati (yakni keluarga) maupun juga bersifat buatan (misalnya dalam hal ini jamaah umrah first travel) .

Secara genetis sudah ada faktor yang membentuk tingkah laku manusia, baik itu egoistis maupun altruistik. Menurut teori sosiobiologi manusia dilatarbelakangi oleh materalism, sehingga kodrat manusia disamakan begitu saja dengan kodrat biologis (turunan). Padahal manusia sendiri adalah maakhluk yang memiliki kemampuan belajar. Sosiobilogi dengan demikian harus diimbangi dengan ilmu sosiologi ( yang mana terlepas dari biologi) dan filsafat sosial yang meneliti hakekat dan pemaknaan secara lebih komprehensif dan mendalam. Dalam ilmu sosialitas sendiri kemudian muncul dua posisi ekstrim yakni Individualisme dan Kolektivisme. Dua posisi ekstrim yang saling bertolak belakang. Individualisme, pada teori ini nilai utama yang dijunjung adalah individual sementara kebersamaan bersifat sekunder. Hak individu kemudian berkuasa atas dirinya. Seperti pada kasus first travel ini, pengelola jasa perjalanan first travel menjunjung tinggi individualisme. Hal ini terlihat dari tidak pedulinya dengan jamaah haji yang telah memberikan amanah. Pihak first travel secara gamblang dan terang terangan mendahulukan dan menjunjung tinggi keinginannya, tidak peduli dengan yang lain. Hal ini kemudian berpengaruh negatif bagi yang lain, selain pihak first travel, yang kemudian bisa disebut individualisme adalah negara. Mengapa demikian karena dalam kasus ini negara tidak menjalankan tugasnya sebagamana 
mestinya. Setidaknya 3 hak fundamental warganegara diabaikan oleh negara. Pertama perjuangan jamaah haji dalam memperjuangkan hak nya tidak dihargai dan tidak didapatkan. Sebab negara bersifat pasif dan tidak proaktif sama sekali. Kemudian yang kedua hak-hak dari jamaah haji tidak terlindungi. Hal ini terlihat ketika jamaah umrah yang menjadi korban mencoba mencari perlindungan kepada negara, tetapi kemudian yang didapatkan adalah negara merampas uang jamaah umrah. Ketiga adalah hak untuk dipenuhi hak-haknya sebagaimana mandat dari sebuah konstitusi. Dalam hal ini negara belum menjalankan amanat konstitusi untuk melindungi hak-hak warga negaranya.

Menurut teori sosialitas aku dan yang lain, aku adalah realitas dan yang lain juga realitas. Makna dari hubungan ini adalah terjadi jika manusai melampaui hubungan antara subjek dan objek, yaitu masuk pada hubungan intersubjektif. Dimana intersubjektifitas akan menjadi mungkin jika setiap subjek menerima kebenaran yang objektif. Selain itu intersubjektifitas adalah jalinan antar subjek yang berdiri diatas satu objek transendental. Pengalamanku bukanlah pengalaman yang lengkap. Pengalaman ini menjadi lengkap jika berhadapan dengan "yang lain" . Sehingga dengan demikian yang lain adalah "Aku juga". Sesuatu yang paling dekat dengan diriku adalah diriku sendiri, hidupku sendiri. “Yang lain” bisa menjadi ancaman atau pemenuhan atasku. Hal ini juga berlaku bagi "yang lain” dalam berelasi dengan aku. Lalu kemudian apa yang dibutuhkan dalam relasi semacam ini? Adalah kepercayaan. Namun aku berpendapat lain bahwa manusia saat masih dipenuhi kuasa nafsu. Sehingga mengabaikan yang lain. Manusia saat ini hanya bisa mengenal dirinya sendiri, manusia saat ini tidak bisa mengerti bahwa persoalan hidup bukan hanya dirinya sendiri, melainkan yang lainnya juga. Dengan ego yang tinggi manusia mencari pembelaan atas dirinya, yang membuat dirinya semakin terlihat bodoh. Pada kasus first travel pelaku yang sekaligus pemilik bisnis fisrt travel ini hanya mementingkan dirinya sendiri. Bahkan tanpa pengalaman berani melakukan kegiatan yang sakral. Pelaku bukan hanya bersalah dihadapan manusia yang telah ditipu, melainkan juga bersalah pada tuhan. Sebab apa yang ditipu dari korbannya adalah apa yang diperjuangkan dari korban kepada tuhan. Banyak jamaah yang berusaha keras mendapatkan uang untuk beribadah ke tanah suci, tetapi kemudian gagal akibat sifat egois pelaku.

Pengalaman pelaku menjadi lengkap seketika setelah berhadapan dengan orang banyak, dia akhirnya mendapatkan pengalaman mengenai keburukan yang berdampak pada hidupnya saat ini. Setelah apa yang dilakukan selama ini, dan akibat yang diterima saat ini. Belum tentu ia bisa belajar dari pengalamannya, melainkan juga suatu saat bisa 
kembali lagi melakukan kejahatan yang sama. Ketika seseorang sudah melakukan kejahatan, ada dua kemungkinan yang terjadi setelahnya, seperti kasus first travel, pelaku bisa berubah dan belajar dari pengalaman, ataupun juga bersifat masa bodoh dan mencari pembelaan dari keburukannya.

Sedikit lika liku perjalanan kasus dari fist travel yakni pertama kali bisnis yang dijalankan pelaku adalah bisnis perjalan biasa, lalu tidak ada yang berminat sampai awal berdiri hingga beberapa tahun kemudian. Lalu kemudian dengan berbekal pengetahuan dari internet pelaku mendirikan usaha biro perjalanan umroh sampai akhirnya menipu jamaah dan akhirnya pelaku ditangkap oleh pihak berwajib. Dari lika liku perjalanan pelaku bisa terlihat bahwa pelaku tidak memiliki kompetensi untuk melakukan bisnis perjalanan ibadah tersebut. Hal yang tak kalah penting adalah pelaku tidak takut terhadap pertanggung jawaban dihadapan Tuhan kelak. Mengingat yang ditipu bukan hanya jamaah tetapi juga tuhan. Manusia semacam ini sungguh memiliki hati nurani yang jelek.

Selanjutnya adalah membahas mengenai kasus first travel menggunakan teori dalam bab 3 yakni soal yakni Intelek,Kehendak, dan Dinamika manusia. Dalam bab III ini dijelaskan, bahwa intelek adalah persoalan mengerti, dan sedangkan kehendak adalah soal kemauan. Yang dengan demikian, hakikat dari keduanya adalah mengerti dan menghendaki, kemudian dimaknai sebagai inti dari sebuah kegiatan. Lebih jauh lagi intelek bertugas memilah sedangkan kehendak mengapresiasi. Sehingga dapat dijabarkan intelek adalah persoalan manusia dalam memaknai setiap kegiatan yang dilakukan. Intelek manusia berhubungan dengan pertimbangan akal manusia dalam melakukan sesuatu, apakah hal yang dilakukan telah memenuhi inteleknya atau belum. Hal ini seperti pada kasus ini yakni intelek dalam hal ini pertimbangan dari pelaku dalam melakukan kejahatan ini terhadap jamaah, dan persoalan mengambil keputusan dalam melakukan kegiatan ini. Sedangkan jika ditinjau dari kehendak, yakni merupakan kegiatan yang tanpa ada pertimbangan lebih jauh seperti intelek. Bisa dikatakan juga jika kehendak dikendalikan oleh nafsu.

Manusia dapat dikatakan bahwa disatu pihak punya kebebasan, tetapi di lain pihak juga tergantung. Hal ini terlihat dari manusia ketika memutuskan maka dia bebas, namun setelahnya dia harus tunduk pada apa yang sudah diputuskan. Pada aliran determinisme mengatakan bahwa, Manusia itu tidak bebas dan ditentukan oleh unsurunsur lain. Sementara itu, aliran Indeterminisme mengatakan bahwa, manusia itu bebas 
mutlak. Maka dalam hal ini konflik yang kemudian terjadi adalah, dalam memahami kebebasan terjadi antara paham Determinisme dan paham Indeterminisme. Dalam kasus fisrt travel jika dikaitkan pada teori determinisme berarti tindakan manusia ini tidak bebas karena terdapat unsur lain yakni hukum. Manusia ini berlaku tidak bebas dihadapan hukum. Tetapi jika ditinjau dari teori indeterminisme manusia bebas melakukan apa saja sepanjang dia melakukan dengan tahu, mau dan bebas. Dari teori ini jika diterapkan maka tidak akan ada hukum yang mengatur kesalahan manusia. Karena paham bahwa manusia adalah manusia yang bebas, bebas melakukan apa saja, bebas bertindak apa saja dan bebas memperlakukan siapa saja dengan apa saja. Namun agaknya teori ini tidak benar, karena manusia sesungguhnya makhluk sosial, makhluk yang butuh orang lain, makhluk yang bergantung dengan orang lain. Oleh sebab bergantung dengan orang lain, tentunya orang akan berlomba-lomba membangun hubungan baik dengan orang lain, agar dirinya pun bisa mendapatkan manfaat atas adanya orang lain, maka dengan demikian ada manusia yang memanfaatkan hubungan dengan orang lain untuk kebaikan maupun memanfaaatkan untuk kejelekan.

Konflik yang terjadi antara paham Deterministik dan paham Indeterministik dapat diuraikan dalam bahasan berikut ini : jika dasar yang dipakai tidak bebas dan dijelaskan secara Spiritualistik; bahwa kehendak atau kebebasan manusia ternyata sudah diarahkan pada hal yang baik. Tetapi pada kenyataanya, kehendak manusia itu ternyata masih kebebasan. Meski terarah pada yang baik, hal ini karena kepentingan dari subjek, sementara itu dari kacamata materialistik, bahwa subjek itu seharusnya tidak bebas, karena seluruh kegiatan manusia telah diatur pada keharusan alamiah. Sintese dari semua itu adalah bahwa manusia tidak hanya ditentukan oleh suatu determinasi atau indeterminasi. Kegiatan manusia selalu diwarnai dengan aku yang bebas dan aku yang terarah kepada sesuatu. Dari teori ini jelas bahwa yang dilakukan pelaku bisnis first travel telah mengambil garis kecil dari teori kebebasan menurut sintese deterministik maupun indeterministik. Dia dengan bebas melakukan kegiatan yang menurutnya benar, tanpa tahu dampak yang ditimbulkan dari kegiatannya ini.

Manusia menurut dinamika sebagai realitas berarti manusia yang hidup berarti aktif secara terus menerus, walaupun manusia dalam kondisi tertidur, tetapi bagian dari sel sel manusia tidak pernah tertidur dan bekerja terus menerus. Manusia juga tak dapat 
dipisahkan dari dinamika spiritual, dalam diri manusia tak dapat dipisahkan antara jasad manusia dengan spiritual. Karena tidak ada spiritual manusia tanpa adanya badaniah. Mengenai keaktifan dan kesadaran ada dua aspek yakni aspek kognitif dan aspek afektif, dan dari sini masih harus dibedakan lagi bagian keindraan dan bagian rohani. Tetapi dua bagian ini tak dapat dipisahkan. Dengan demikian dinamika manusia secara garis besar adalah berarti kekuatan yang bergerak, menggerakkan dan mendorong. Jika meninjau kasus ini menurut teori dinamika, dalam prakteknya pelaku telah menggunakan dinamika dalam hidupnya yakni terus bergerak berkarya, dan terus melanjutkan hidupnya, makan minum dan kebutuhan rohaninya, tetapi kemudian yang menjadi kegiatan dalam dinamika hidupnya ada terdapat kesalahan. Kesalahannya yakni melalui dinamika hidupnya, dia membuat orang lain merugi, merasa kesulitan merasa keberatan dan merasa rugi akibat tindakannya. Hal ini tentunya yang tidak baik dari segala perbuatan manusia ini, karena sesungguhnya kegiatan manusia dalam hidup harus menyeimbangkan antara kebutuhan badaniah dan kebutuhan rohaniah. Jika manusia bisa menyeimbangkan keduanya tentunya akan membuat hidup akan lebih bermanfaat bagi yang lain. Dan tentunya hidupnya akan lebih bermakna. 
DAFTAR PUSTAKA

Dewantara, Agustinus. "Filsafat Moral (Pergumulan Etis Keseharian Hidup Manusia). “(2017). 